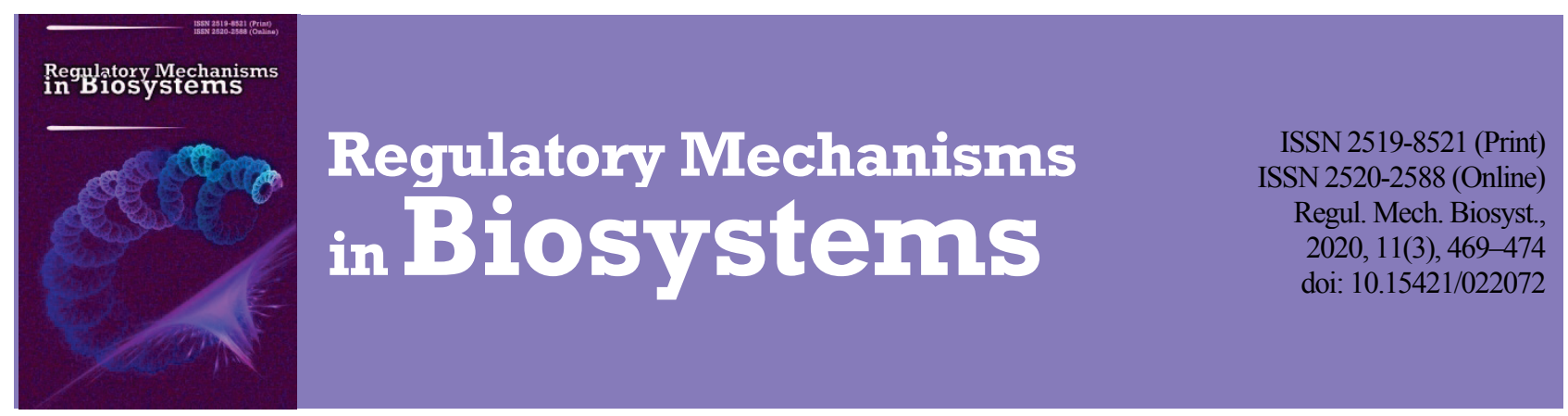

\title{
Genetic analysis of morphological traits of the spike and reproductivity elements of speltoid chemomutant Triticum aestivum
}

\author{
R. A. Yakymchuk*, L. Y. Sobolenko**, S. I. Sorokina** \\ *Institute of Plant Physiology and Genetics, NAS of Ukraine, Kyiv, Ukraine \\ **Pavlo Tychyna Uman State Pedagogical University, Uman, Ukraine
}

Article info

Received 15.07.2020

Received in revised form 22.08.2020

Accepted 24.08.2020

Institute of Plant

Physiology and Genetics of the National Academy of Sciences of Ukraine, Vasylkivska st., 31/17 Kyiv, 03022, Ukraine. Tel.: +38-097-341-89-12. E-mail:

peoplenature16@gmail.com

Pavlo Tychyna Uman State Pedagogical University, Sadova st., 2,

Uman, 20300, Ukraine.

Tel.: +38-096-303-59-82. E-mail:sobolenko@ukr.net

\section{Introduction}

The strategy of selective breeding of soft wheat at the contemporary stage of the agriculture is oriented towards increasing its yield and adaptive potential while maintaining or improving grain quality (Guzman et al., 2016; Diordiieva et al., 2018). The contemporary norm of annual improvement of yield for the main agricultural crops accounts for $0.8-1.2 \%$, which should be increased to satisfy the increasing demand for plant products ( $\mathrm{Li}$ et al., 2018). In recent years use of hybridization, back-cross breeding and selection has been accompanied by successful combination of the desirable traits related to grain yield, adaptation to abiotic loads, resistance to diseases and protection against pests in one genotype of wheat. However, the use of such methodology of genetic improvement of the existing varieties of wheat has led to narrowing of their gene fund and development of similarity according the genetic potential of features important for selective-breeding (Breseghello, 2013; Mondal et al., 2016). Despite the increasing demand for food products of high quality, the yield continues to be the main determining indicator of profitability of production of grain crops. The recently created highly-productive varieties are often characterized by insufficient quality due to the low content of pro-
Yakymchuk, R. A., Sobolenko, L. Y., \& Sorokina, S. I. (2020). Genetic analysis of morphological traits of the spike and reproductivity elements of speltoid chemomutant Triticum aestivum. Regulatory Mechanisms in Biosystems, 11(3), 469-474.

Long use of the methods of direct intraspecies hybridization in the selective breeding of varieties of Triticum aestivum L. has led to narrowing of their gene fund and close similarity of the genetic potential of their selective breeding traits. Using the method of experimen-

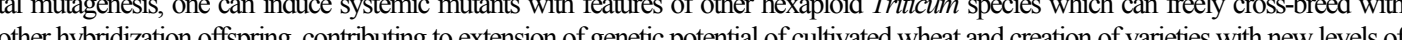
manifestation of economically beneficial traits. We studied the pattern of inheritance of morphological traits of the ear, length of the stem and the elements of productivity of speltoid chemomutant of $T$. aestivum. For the genetic analysis we used hybrids $\mathrm{F}_{1}$ and $\mathrm{F}_{2}$ of soft wheat obtained by cross-breeding speltoid macromutant (Smuhlianka speltoid), induced by the impact of aqueous solution of N-nitroso-Nmethylurea (NMU) in the concentration of $0.025 \%$ on the seeds of Smuhlianka variety, with plants of Smuhlianka variety (Erythrosperthe elements of productivity in $\mathrm{F}_{1}$ hybrids, we calculated the extent of phenotype domination. In populations of $\mathrm{F}_{2}$, we examined plants and red colour of the glumes indicated the dominant pattern of inheritance. The high level of phenotype domination of length of the stem and dominant types. Taking into account the segregation according to the features of spike morphology, awnedness and colour of glumes, the plante combinations of respectively Smuhlianka speltoid $\times$ Smuhlianka and Smuhlianka speltoid $\times$ Podolianka. We determined that the obtained results are the consequences of dihybrid linkage which corresponds to the theoretical proportion of $12: 3: 1$. Segregation into non-aristate and aristate plants corresponds to the proportion of monogene segregation of $3: 1$. Within separately distinguished phenotype classes, no independent inheritance of the shape of the ear quas observed. Dihybrid segregation of $\mathrm{F}_{2}$ plants into speltoid, squarehead and varieties Lutescence/Erythrospermum with quantitative superiority of speltoid plants suggests the control of the trait by two non-allele genes with epistatic interaction. The red colour of the glines indicates the dominant monogenic pattern of inheritance. Absence of independent inheritance of the shape of the ear and

Keywords: soft wheat; systemic mutations; ear morphology; elements of productivity; hybrid combinations; extent of phenotype domination.

teins and minerals in the grain (Sharma et al., 2016; Suchowilska et al., 2020). Chasing fast improvement of the genetic potential of yield has led to cultivation of mostly Triticum aestivum L. and T. durum Desf. and cessation or minimization of cultivation of other species of Triticum genus (Voss-Felsetal., 2019). In 2018-2019, the global production of wheat was assessed at $735 \mathrm{mln}$. tons, and allohexaploid bread wheat (T. aestivum) accounted for around $94 \%$ of the total production. In 2017-2018 the production of allotetraploid hard wheat (T. durum) equaled about $37.5 \mathrm{mln}$. tons with more than $5 \%$ share of the global production of grain crops. Other species of wheat, particularly allohexaploid spelta (T. spelta L.), allotetraploid farro (T. dicoccum Schrank) and diploid einkorn wheat (T. monococcum L.) are grown only in separate regions of the world, including the EU, the Balkans, and the Indian Subcontinent, where they occupy large areas (Callejo et al., 2015; Boukid et al., 2018). Evolution of the selective breeding of plants caused genetic erosion, and thus, loss of genetic diversity. The analysis of the genome of bread wheat revealed that its polyploidization and domestication from three diploid ancestors resulted in the loss of 10,000 to 16,000 genes and several gene families. At the same time, as a result of prolonged use of limited numbers of offspring varieties in hybridization and selection of high-yield varieties for 
certain ecological conditions, many beneficial genes are likely to have been lost over the recent decades (Breseghello, 2013; Khoury et al., 2014; Tadesse et al., 2016). Therefore, there is a serious need to work beyond the model of contemporary agriculture and enrich the genome of wheat again by introducing embryonic plasma with high non-homogenity.

A number of scientific institutions which work on the development of varieties of wheat with a high level of productivity, resistance to unfavourable factors of the environment and high quality of grain have included the methods of cross-breeding of geographically remote varieties with the traits which correspond to the needs of contemporary agriculture (Xie et al., 2015; Longin et al., 2016; Boukid et al., 2018). Use of interspecies hybridization in the Triticum genus makes it possible to enlarge the genetic potential of cultivated wheat and develop a variety with new levels of manifestation of traits according to their genetic improvement. In this respect, wild-growing, semi-wild and long time forgotten species are donors of high content of protein, gluten, lysine, microelements, antioxidants and resistance to low amounts of macroelements in the soil (nitrogen, phosphorus, potassium), diseases and pests (Longin et al., 2016). As a result of remote hybridization with participation of parents with different sets of alleles, not only interspecies transfer of genes is possible, but emergence of a different type of micromutation, which in some cases can be useful for selective breeding (Hlebova \& Baryisheva, 2016). The presence of genome composition homologous to T. aestivum (AuBD) and inherently determined agriculturally valuable traits (modest requirements in terms of agricultural conditions, clearly expressed positive reaction to nitrogen nutrition, high content of protein in the grain) makes allohexaploid species of spelta wheat ( $T$. spelta) valuable as a source of genetic improvement of the quality of soft wheat (Guzman et al., 2016; Rap et al., 2017; Deordiieva et al., 2018; Suchowilska et al., 2020). Hybrids of T. aestivum and T. spelta could become an interesting alternative way of eliminating unfavourable qualities of spelta and improvement of the nutritive value of bread wheat. The positive results in selective breeding using genotypes from cross-breeding of soft winter wheat with its wild-growing and cultivated relative species obtained by the Institute of Plant Physiology and Genetics of the National Academy of Sciences of Ukraine (IPPG) indicate perspectives of using introgressive recombinative variability in the programs of selective breeding of wheat (Morgun et al., 2016). Selective breeding with the use of remote hybridization entails a number of problems, the most well-known of which is the inability of different species to be cross-bred or infertility of hybrid progeny. They are related not only to the non correspondence of genetic nuclear mechanisms (presence or absence of homologous chromosomes), but also is determined by cytoplasmic inherent factors. Using the method of experimental mutagenesis, it is possible to induce the systemic mutants which have features of other hexaploid species of Triticum and could be cross-bred with the offspring. Induction of speltoid macromutants in soft wheat has been reported by many researchers (Forster et al., 2012; Morgun \& Yakymchuk, 2015; Burdenyuk-Tarasevich, 2017; Yakymchuk, 2019). Loci which underlie speltoid phenotype differences were presumed to be blocks of closely linked genes. At the same time, macromutational transformations are explained not only by the impact of genes or blocks of genes, but also by possible transitions in the dominant or recessive conditions of separate diploid genomes. Rapid inhibition of expression of some productivity indicators, caused by such factors, in such speltoid mutants leads to low productivity, which can be accompanied by high content of protein in grain, similarly to $T$. spelta. Development of speltoid mutants, detection of their morphostructural peculiarities, genetic determination and pattern of inheritance of productivity traits would allow us to assess the further perspectives of the most rational and efficient use of systemic macromutants as donors of selective-breeding valuable characteristics of soft winter wheat. The objective of the study was to determine the pattern of inheritance of morphological features of the ear, length of the stem and elements of productivity of speltoid chemomutant T. aestivum.

\section{Materials and methods}

For the genetic analysis we used $F_{1}$ and $F_{2}$ hybrids of soft winter wheat (T. aestivum), obtained from cross-breeding of speltoid macromutant (Smuhlianka speltoid), induced by influence of aqueous solution of
N-Nitroso-N-methylurea in the concentration of $0.025 \%$ on the seeds of Smuhlianka variety, with the plants of Smuhlianka variety (Erythrospermum variety) and Podolianka (Lutescens variety). Hybrid plants were grown in the fields of the experimental research area of the Institute of Plant Physiology and Genetics of the National Academy of Sciences of Ukraine (IPPG) in the Hlevaha urbanized settlement of Vasylkiv district of Kyiv region. Research on plants of the varieties and the wheat mutant in the husbandries of initial seed production revealed their stability according to the main morphological features.

$F_{1}$ hybrids were planted manually in one row plots of $1.5 \mathrm{~m}$ length and $30 \mathrm{~cm}$ distance between the rows. The sowing was performed according to the following scheme: mother variety - hybrids of the first generation - father variety, using the varieties employed in cross breeding as standards. For the structural analysis we selected 25 plants of both hybrids and father varieties in the stage of complete ripeness, and then determined their parameters of length of the stem and elements of productivity. To determine the character of their inheritance, in F1 hybrids, we determined the extent of phenotype domination (hp) according to Griffing (1950). The data obtained was systematized according to Beil \& Atkins (1965).

The generation of $\mathrm{F}_{2}$ plants was planted as a population in the selective nursery in $10 \mathrm{~m}^{2}$ plots, using thinned-out sowing. By the end of the vegetation, in $\mathrm{F}_{2}$ populations we recorded plants with different combinations of phenotype manifestation of spike morphology traits. In general, in $F_{2}$ populations we examined $400-500$ plants of each one. The reliability of the quantitative differences between the father plants and hybrids was determined using Student's t-criterion. The correspondence of the actual proportion of phenotype classes to the theoretical proportion in $\mathrm{F}_{2}$ was determined according to $\chi^{2}$ criterion.

\section{Results}

Hybrids of the first generation of both combinations of cross-breeding (Smuhlianka speltoid $\times$ Smuhlianka and Smuhlianka speltoid $\times$ Podolianka) were represented by one morphotype: speltoid ear with red glumes and absence of awns, indicating dominant inheritance of traits of speltoid mutant. Determining the variability and the pattern of inheritance of a number of the features in hybrids $\mathrm{F}_{1}$ revealed that separate parameters of the productivity elements are not found uniformly compared with the father varieties (Table 1). Thus, the trait stem length of the first generation hybrids significantly exceeded that in the father variety, being closer to the parameters of the mother plants. Hybrids $F_{1}$ in the combination Smuhlianka speltoid $\times$ Podolianka were significantly higher than father varieties and did not differ by this feature from mother plants. Depending on the combination of cross-breeding, the feature was inherited according to the type of partial positive dominance $(\mathrm{hp}=0.73)$ for Smuhlianka speltoid $\times$ Smuhlianka and over-dominance $(\mathrm{hp}=1.13)$ for Smuhlianka speltoid $\times$ Podolianka. Length of the main ear of $F_{1}$ plants was greater than that of the father variety and close to the parameter of mother plants. The extent of phenotype domination ranged within $0.20-0.61$, suggesting partial positive dominance and intermediate inheritance of the mentioned trait.

General and productive tillering of wheat was characterized by lower variability than other features which form the structure of yield. In $F_{1}$ hybrids, compared with father plants, the parameters of the total and productive tillering did not significantly change and were found to have dominant, partially dominant, intermediate and recessive types of inheritance depending on the combination of cross-breeding.

The number of spikelets in the main ear in $\mathrm{F}_{1}$ hybrids corresponded to the level of the mother variety. However, this parameter in the combination Smuhlianka speltoid $\times$ Podolianka was reliably higher than in the father variety - Podolianka. No significant differences according to this trait were determined between $F_{1}$ hybrids and their speltoid mother variety. The trait of the number of ears in the main ear was inherited as the dominant one with the effect of heterosis. In the combinations Smuhlianka speltoid $\times$ Smuhlianka and Smuhlianka speltoid $\times$ Podolianka, the extent of its phenotype dominance equaled respectively 13 and 1.33 .

The amount of grains from the main ear of $F_{1}$ hybrids significantly exceed such parameter of the mother variety in the cross-breeding combination Smuhlianka speltoid $\times$ Smuhlianka and was significantly lower 
than in the father variety in the combination Smuhlianka speltoid $\times$ Podolianka. The feature was inherited according to the intermediate type ( $\mathrm{hp}=$ $0.11)$ and partial negative dominance $(\mathrm{hp}=-0.58)$. According to the mass of grains from the main ear, $\mathrm{F}_{1}$ hybrids significantly did not differ from any of the father varieties. The parameter of the manifestation of the trait in the combination Smuhlianka speltoid $\times$ Smuhlianka accounted for $2.3 \mathrm{~g}$, corresponding to its average value of the both parents. In combination Smuhlianka speltoid $\times$ Podolianka the parameter of mass of grain from the ear of hybrids equaled $2.2 \mathrm{~g}$, not differing from the level of the father variety. The level of the phenotype dominance varied within $0.2-1.0$, indicating intermediate type of inheritance of the trait and partial positive dominance.

\section{Table 1}

Parameters of the elements of productivity of $F_{1}$ hybrids and the extent of their phenotype dominance $(h p)(n=30, x \pm S D)$

\begin{tabular}{|c|c|c|c|c|c|c|c|c|}
\hline \multirow{4}{*}{\multicolumn{2}{|c|}{ Elements of productivity }} & \multicolumn{7}{|c|}{ Father variety and combinations } \\
\hline & & \multirow{3}{*}{$\begin{array}{l}\text { Smuhlianka } \\
\text { speltoid }\end{array}$} & \multirow{3}{*}{ Smuhlianka } & \multirow{3}{*}{ Podolianka } & \multicolumn{4}{|c|}{ Smuhlianka speltoid $\times$} \\
\hline & & & & & \multicolumn{2}{|l|}{ Smuhlianka } & \multicolumn{2}{|l|}{ Podolianka } \\
\hline & & & & & absolute value of the parameter & hp & absolute value of the parameter & hp \\
\hline \multirow{2}{*}{ Length, $\mathrm{cm}$} & stem & $118.4 \pm 1.7$ & $86.8 \pm 0.5$ & $99.8 \pm 0.7$ & $114.1 \pm 1.3^{* *}$ & 0.73 & $119.6 \pm 1.6^{*}$ & 1.13 \\
\hline & main ear & $13.5 \pm 0.6$ & $9.9 \pm 0.4$ & $9.4 \pm 0.2$ & $12.8 \pm 0.4^{*}$ & 0.61 & $11.9 \pm 0.3^{* *}$ & 0.20 \\
\hline \multirow{4}{*}{ Number of } & stems & $6.0 \pm 0.4$ & $5.6 \pm 0.3$ & $6.3 \pm 0.4$ & $5.6 \pm 0.3$ & -1.00 & $6.0 \pm 0.4$ & 1.00 \\
\hline & productive stems & $4.4 \pm 0.3$ & $4.8 \pm 0.2$ & $5.2 \pm 0.3$ & $4.7 \pm 0.2$ & 0.50 & $5.3 \pm 0.3^{* *}$ & 1.25 \\
\hline & spiklets in the main ear & $19.2 \pm 0.4$ & $19.1 \pm 0.3$ & $16.8 \pm 0.3$ & $19.8 \pm 0.3$ & 13.00 & $19.6 \pm 0.4^{*}$ & 1.33 \\
\hline & grains from the main ear & $38.6 \pm 1.2$ & $47.6 \pm 1.6$ & $46.7 \pm 1.6$ & $43.6 \pm 1.5^{* *}$ & 0.11 & $40.4 \pm 1.6^{*}$ & -0.58 \\
\hline \multirow{3}{*}{ Mass, gr } & grains from the main ear & $2.0 \pm 0.2$ & $2.5 \pm 0.1$ & $2.2 \pm 0.2$ & $2.3 \pm 0.2$ & 0.20 & $2.2 \pm 0.2$ & 1.00 \\
\hline & grains from the plant & $8.2 \pm 0.6$ & $9.2 \pm 0.6$ & $9.9 \pm 0.7$ & $8.9 \pm 0.6$ & 0.40 & $9.6 \pm 0.5$ & 0.65 \\
\hline & 1,000 grains & $49.4 \pm 1.6$ & $48.7 \pm 1.8$ & $46.9 \pm 2.0$ & $49.1 \pm 1.3$ & 0.17 & $47.6 \pm 1.8$ & -0.44 \\
\hline
\end{tabular}

Notes: * - difference compared with the father variety was statistically reliable at $\mathrm{P}<0.05 ; * *$ - difference compared with mother variety was statistically reliable at $\mathrm{P}<0.05$.

The mass of grains from plants in $\mathrm{F}_{1}$ hybrids in cross breeds Smuhlianka speltoid $\times$ Smuhlianka and Smuhlianka speltoid $\times$ Podolianka accounted for 8.9 and $9.6 \mathrm{~g}$, which exceeded by 0.7 and $1.4 \mathrm{~g}$ the parameter of the examined trait in the speltoid mutant and was less by $0.3 \mathrm{~g}$ than the father varieties. Taking into account the extent of phenotype dominance ( $\mathrm{hp}=0.40$ and 0.65 ), we can draw a conclusion that the trait of grain weight from the plant indicates intermediate inheritance and partial positive dominance. In $\mathrm{F}_{1}$ hybrids no difference was determined according to the mass of 1,000 grains compared with the samples included in cross breeding. The level of phenotype dominance accounted for $-0.44-+0.17$, which is characteristic for the intermediate type of inheritance.

Taking into account segregation according to the features of the ear morphology, awnedness and colour of glumes, the plants of $\mathrm{F}_{2}$ population were divided into phenotype classes of 12 and 6 in combinations, respectively Smuhlianka speltoid $\times$ Smuhlianka and Smuhlianka speltoid $\times$ Podolianka (Fig. 1). Actual segregation according to the shape of the ear in each $\mathrm{F}_{2}$ population is presented in Table 2 . Among 402 plants examined in the second generation in the combination Smuhlianka speltoid $\times$ Smuhlianka we found 320 - with speltoid ear, 61 - with ear of Erythrospermum variety (hereinafter - normal ear) and 21 - squarehead ear; and in the cross bred combination Smuhlianka speltoid $\times$ Podolianka, among 450 examined plants, 344 plants were found to have speltoid ear, 72 - ear of Lutescens variety (hereinafter - normal ear) and 34 - squarehead ear. Based on the data of hybridological analysis, we determined that the obtained results are the consequence of dihybrid segregation, which reliably corresponds to the theoretical ratio $12: 3: 1\left(\chi^{2}=4.56\right.$ and 3.16 , respectively).

The population of $F_{2}$ of Smuhlianka speltoid $\times$ Smuhlianka plants was studied for presence and absence of awns. In soft wheat, the awnedness is a recessive feature. It disappears in $\mathrm{F}_{1}$ hybrids and, depending on features of spike morphology and colour of glumes, expresses in $\mathrm{F}_{2}$. Segregation into non-aristate and aristate plants accounts for $313: 89\left(\chi^{2}=\right.$ $1.75)$, which reliably corresponded to the proportion of monogene segregation equaling $3: 1$ (Table 2).

In the $\mathrm{F}_{2}$ population, among speltoid plants, we counted those with aristate ears. Their total number was found to be insufficient to confirm the reliabilities of the proportion of $3: 1$. Among plants with squarehead and normal ears, there were by contrast more aristate than non-aristate plants (Table 3). As a result of crossing over in the region of probable localization of $B_{I}$ and $Q$ genes $5 \mathrm{~A}$ chromosome in combinations of mutant Smuhlianka speltoid and plants of Smuhlianka variety, samples with recombined traits occurred, the share of which in the conditions of independent combination was less than expected. Thus, within separately distinguished phenotype classes, no independent inheritance of the traits of ear shape and awnedness were seen. Therefore, genes which determine the indicated traits compose one group of segregation which causes restrictions on their free combination.

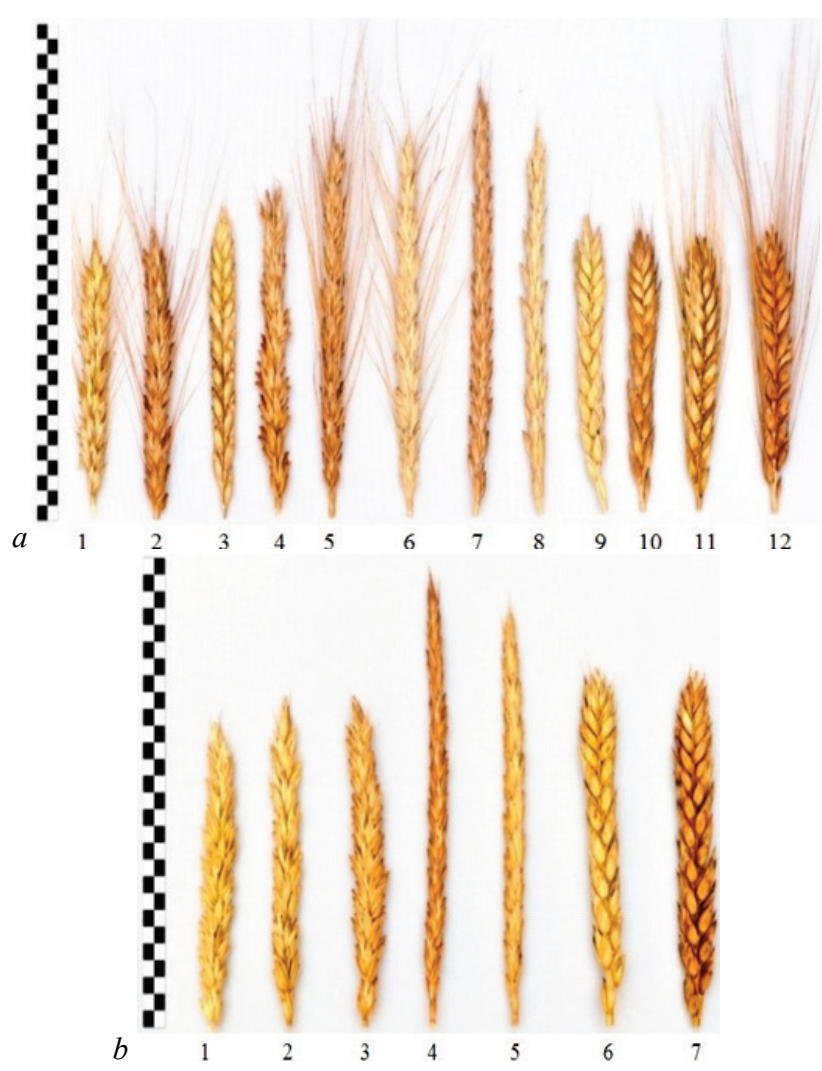

Fig. 1. Classes of segregation according to combinations of traits of shape and colour of ear in $\mathrm{F}_{2}$ plants of combinations $(a)$ Smuhlianka speltoid $\times$ Smuhlianka, $(b)$ Smuhlianka speltoid $\times$ Podolianka; a: 1 -normal aristate white, 2 -normal aristate red, 3 -normal non-aristate white, 4 -normal non-aristate red, 5 - speltoid aristate red, 6 - speltoid aristate white, 7 speltoid non-aristate red, 8 - speltoid non-aristate white, 9 - squarehead non-aristate white, 10 - squarehead non-aristate red, 11 - squarehead aristate white, 12 - squarehead aristate red; b: 1 - normal white, 2 -nor-

mal red, 3 - speltoid red, 4-speltoid white, 5-squarehead white, 6 - squarehead red; ruler scale $-5 \mathrm{~mm}$

According to the results of the analysis of the character of inheritance of colour of the glumes, their red colour in $\mathrm{F}_{2}$ plants, regardless of the combination of cross breed, retains a constant tendency towards dominance over white colour (Table 4). In the combination Smuhlianka speltoid $\times$ Smuhlianka, the segregation according to the traits of colour of the ear 
equaled 318 red-eared and 84 white-eared plants, corresponding to the proportion $3: 1\left(\chi^{2}=3.61\right)$ of monogenic inheritance. The same proportion was found during the analysis of segregation of the traits in the population of the generation of $\mathrm{F}_{2}$ plants in the cross-bred combination Smuhlianka speltoid $\times$ Podolianka: 350 with red ear and 100 with white ear $\left(\chi^{2}=1.85\right)$. Therefore, the trait of red colour of glumes determines the dominant monogenic character of inheritance regardless of genotypes of soft wheat included in cross-breeding combinations with the speltoid mutant.

Table 2

Segregation in $\mathrm{F}_{2}$ hybrids according to the shape of the ear and awnedness

\begin{tabular}{|c|c|c|c|c|c|c|}
\hline \multirow{2}{*}{ Combinations } & \multirow{2}{*}{$\begin{array}{c}\text { Ear } \\
\text { phenotype }\end{array}$} & \multicolumn{5}{|c|}{ Segregation } \\
\hline & & actual & expected & ratio & $\chi^{2}$ & $\chi_{\text {test }}^{2}$ \\
\hline \multirow{5}{*}{$\begin{array}{l}\text { Smuhlianka } \\
\text { speltoid } \times \\
\text { Smuhlianka }\end{array}$} & speltoid & 320 & 301.5 & \multirow{3}{*}{$12: 3: 1$} & \multirow{3}{*}{4.56} & \multirow{3}{*}{5.99} \\
\hline & normal & 61 & 75.4 & & & \\
\hline & squarehead & 21 & 25.1 & & & \\
\hline & non-aristate & 313 & 301.5 & \multirow{2}{*}{$3: 1$} & \multirow{2}{*}{1.75} & \multirow{2}{*}{3.84} \\
\hline & aristate & 89 & 100.5 & & & \\
\hline \multirow{3}{*}{$\begin{array}{c}\text { Smuhlianka } \\
\text { speltoid × } \\
\text { Podolianka }\end{array}$} & speltoid & 344 & 337.5 & \multirow{3}{*}{$12: 3: 1$} & \multirow{3}{*}{3.19} & \multirow{3}{*}{5.99} \\
\hline & normal & 72 & 84.4 & & & \\
\hline & squarehead & 34 & 28.1 & & & \\
\hline
\end{tabular}

Table 3

Segregation of hybrids according to the combinations of traits of awnedness and ear shape in combination Smuhlianka speltoid $\times$ Smuhlianka

\begin{tabular}{|c|c|c|c|c|c|c|c|c|c|}
\hline \multirow[b]{2}{*}{$\begin{array}{l}\text { Segre- } \\
\text { gation }\end{array}$} & \multicolumn{9}{|c|}{ Phenotype of the ear } \\
\hline & $\begin{array}{l}\text { speltoid } \\
\text { non- } \\
\text { aristate }\end{array}$ & $\begin{array}{c}\text { speltoid } \\
\text { aristate }\end{array}$ & $\begin{array}{c}\chi^{2} \\
3: 1\end{array}$ & $\begin{array}{c}\text { square } \\
\text { head } \\
\text { non- } \\
\text { aristate }\end{array}$ & $\begin{array}{c}\text { square } \\
\text { head } \\
\text { aristate }\end{array}$ & $\begin{array}{c}\chi^{2} \\
3: 1\end{array}$ & $\begin{array}{c}\text { normal } \\
\text { non- } \\
\text { aristate }\end{array}$ & $\begin{array}{l}\text { normal } \\
\text { aristate }\end{array}$ & $\begin{array}{c}\chi^{2} \\
3: 1\end{array}$ \\
\hline Actual & 294 & 26 & & 9 & 12 & & 10 & 51 & 111.7 \\
\hline Expected & 240 & 80 & 8.0 & 15.75 & 5.25 & $1.5 /$ & 45.75 & 15.25 & 4 \\
\hline
\end{tabular}

Note: $\chi_{\text {test }}^{2}=3.84$.

Table 4

Segregation of $\mathrm{F}_{2}$ hybrids according to colour of the ear

\begin{tabular}{lccccc}
\hline \multirow{2}{*}{$\begin{array}{c}\text { Cross-bred } \\
\text { combination }\end{array}$} & Segregation & \multicolumn{4}{c}{ Ear phenotype } \\
\cline { 3 - 6 } & & red & white & $\begin{array}{c}\text { proportion } \\
\text { of red to white }\end{array}$ & $\chi^{2}$ \\
\hline $\begin{array}{l}\text { Smuhlianka speltoid } \times \\
\text { Smuhlianka }\end{array}$ & $\begin{array}{c}\text { actual } \\
\text { expected }\end{array}$ & 318.0 & 84.0 & $3: 1$ & 3.5 \\
Smuhlianka speltoid $\times$ & actual & 350.0 & 100.5 & & \\
Podolianka & expected & 337.5 & 112.5 & $3: 1$ & 1.85 \\
\hline
\end{tabular}

Note: $\chi_{\text {text }}^{2}=3.84$.

\section{Discussion}

Analysis of morphological traits of the ear and the elements of productivity of father varieties and simple $F_{1}$ hybrids revealed that speltoid form of the ear, red colour of the glumes and non-awnedness was dominant, and such quantitative parameters as length of the main stem and the number of spikelets in the main ear were close to those of the speltoid mutant. Simultaneous improvement of all economically valuable traits is often complicated due to negative correlation between them, caused by segregation of the genes in chromosomes and presence of genes with pleiotrophic effect (Schulthess et al., 2017; Neyhart et al., 2019). One of the most important traits which breeders are willing to improve is yield. It is determined as correlation of dependent parameters such as height of plant, period of earing, mass of a thousand grains, number of grains in one ear and mass of the ear (Schulthess et al., 2017). Most selective-breeding valuable traits belong to the category of quality, each controlled by a complex genetic system. Formation of a separate trait in the process of ontogenesis occurs under the impact of various factors, particularly environment, genotype and their interaction (Voss-Fels et al., 2019).

Length of the stem in $F_{1}$ hybrids was inherited according to the type of partial positive dominance and over-dominance, indicating such difficulties in the selective breeding as short stems in conditions involving a speltoid mutant in cross-breeding combinations. The feature of length of main stem, compared with the stem length, was less dependent on the environmental factors, suggesting the possibility of effectively carrying out the selection of unique genotypes in hybrid populations (Mukhordova, 2019). The length of the main ear, as the potential indicator of the yield of its grains, is one of the most important elements of productivity of winter wheat plants. The same peculiarity is seen according to size of grain. This is one the most accessible elements of the structure of the yield for conducting individual selection for productivity in the hybrid populations which segregate (Cheng et al., 2015). The adaptive character of interaction of genes of the speltoid mutant and varieties of soft wheat which control the trait of number of spikelets in the main ear was found in our research and that of other authors (Simonov et al., 2015; Guo et al., 2018).

Taking into account that size of grain practically does not change under the influence of environmental conditions, determining genetic values of mass of 1,000 grains and the character of their inheritance in the conditions of cross-breeding speltoid forms with soft wheat is essential for creating new varieties (Cheng et al., 2015; Mukhordova, 2019). The results obtained confirm the data obtained by other scientists on the pattern of inheritance of mass of 1,000 grains as one of the main parameters during selection of valuable hybrid varieties of wheat, mostly according to the type of over-dominance and to a lower extent - according to partial or incomplete dominance of the father variety with a greater or lesser degree of manifestation and depression (Ataei et al., 2017; Valekzhanin \& Korobeinikov, 2019).

In $\mathrm{F}_{2}$, the quantitative advantage was observed for plants with speltoid ear above plants with squarehead and normal ear shapes. A peculiarity of segregation in the second generation is emergence of the trait of squarehead ear in the group of plants of the surveyed populations, which was absent in the father varieties. Normal shape of the ear of offspring produced by Smuhlianka and Podolianka was recessive in relation to speltoid type, but at the same time it was dominant in relation to the squarehead type. The probable reason for such segregation of the traits may be the epistatic interaction of genes which causes dominance of their expression in the following sequence: speltoid $>$ Erythrospermum/Lutescens $>$ squarehead. Other scientists (Simonov et al., 2015; BurdenyukTarasevich, 2017) also discovered that speltoids, in the conditions of crossbreeding and individual selections in different generations, manifest squareheads, and squareheads by contrast manifest speltoids. The research revealed that mutants with speltoid and squarehead features of the ear were genetically related to each other. The results of a number of studies on determining inheritance of the feature of speltoidness also indicate their dominant pattern (Morgun et al., 2016; Burdenyuk-Tarasevich, 2017; Simonov et al., 2017). However, summing up the results of direct and reverse cross-breedings of speltoid mutant and soft wheat, we determined that the pattern of inheritance of speltoidness does not correspond to generally-known proportions and, depending on the partner in cross-breeding, the trait is manifested as either recessive or dominant (Burdenyuk-Tarasevich, 2017). Despite the diverse nature of speltoid mutants, their emergence is also related to the changes affecting $5 \mathrm{~A}$ chromosome: loss of chromosome, deletion of locus carried by $Q$ gene, and mutation of $Q$ in $q$. The latter can have monogenic recessive character, monogenic dominant and dominant with expression of recessive epistasis. Gene $Q$ is identified to family of transcription factors of APETALA-2, located on the long arm of $5 \mathrm{~A}$ chromosome and regulates threshing in polyploid species of wheat and has a pleiotrophic effect on several other important traits, including the length and the shape of the ear, fragility of its rachilla, height of the plant, size of gain and time of ear formation (Simonov et al., 2015; Konopatskaia et al., 2016). Mutation in only one pair of nucleotides in alleles of $Q$ gene changed the aminoacid in position 329 , which was significant in the process of domestication of wheat. Polyploid species of wheat have additional homeological loci of $Q$ gene on 5B and 5D chromosomes. Analysis of $5 \mathrm{~B} q$ and $5 \mathrm{D} q$ revealed that $5 \mathrm{~Bq}$ is a pseudogene which codes the complete protein, but takes part in regulation of expression of $5 \mathrm{~A} Q$ and $5 \mathrm{D} q$, and combination of $5 \mathrm{~A} Q, 5 \mathrm{~B} q$ and $5 \mathrm{D} q$ loci is important for the formation of the ear with free threshing (Konopatskaia et al., 2016). Also, it is possible that in this process a role is also played by regulatory genes which control the expression of dozens of genes, since only single mutation in their sequence could lead to significant changes in phenotype (Suchowilska et al., 2020). 
From the practical perspective, speltoids with typical ear of soft wheat and squareheads are the most valuable because these forms have productive ear with easy threshing (Diordiieva et al., 2018).The squareheadness feature has a varied genetic nature. The reason for its development may be polysomy, aberration or genetic mutations. The latter usually have a monogenic recessive pattern, monogenic dominant and dominant with expression of recessive epistasis (Yakimchuk, 2019). Emergence of squarehead type of the ear also is attributed to the effect of dosage of q allele which is hypomorphic in relation to $Q$, and the threshold for the normal shape of the ear is around between $4 q$ and $5 q$. Increase in the dose of $q$ allele leads to emergence of ears of squarehead types (Xu et al., 2018). Emergence of plants with squarehead ears among hybrids is possible in the context of effect of other squarehead-underlying genes along with the $\mathrm{C}$ gene controlling the density of the ear. Those are recessive genes detected in the presence of $Q$ gene. Density of the ear is regulated also by $L_{l}$, $L_{2}$ extender genes. In the presence of recessive alleles of all these genes ( $\mathrm{CCl}_{1} l_{1} l_{2} l_{2}$ genotype), a relatively short, dense clavate ear of squarehead type develops in hexaploid wheat (Yurchenko \& Voloshchuk, 2016).

Numerous multi-year studies conducted on different varieties of wheat demonstrated that detection of traits of awnedness could be due to influences of genes of almost all chromosomes, including modifier genes, and also genotypic environment and gene regulators. However, in most examined samples of soft wheat, non-awnedness is controlled by one $B_{l}$ dominant gene of 5AL chromosome (Huang et al., 2020; Würschum et al., 2020). Absence of the awnedness in $F_{1}$ hybrids, inherited from the speltoid mutant and expression of aristate forms among plants of $\mathrm{F}_{2}$ generation confirms the fact of dominance of non-awnedness over awnedness.

The dominant $B_{I}$ gene is located in the telemetric region of the long arm of 5A chromosome (Simonov et al., 2015), where also the ear shapedetermining $Q$ gene is localized. Therefore, we can presume that genes which determine the shape of the ear and non-awnedness of examined speltoid mutants are linked together. This presumption is confirmed by segregation inside phenotype classes of $F_{2}$ plants with speltoid, squarehead and normal types of the ear of pants into aristate and non-aristate ones.

\section{Conclusions}

In the induced speltoid chemomutant, in the conditions of crossbreeding with soft winter wheat, the traits of speltoid type of the ear, nonawnedness and red colour of the glumes determine the dominant character of inheritance. Quantitative parameters of the elements of productivity such as length of stem, length of the ear, number of spikelets in the main ear in hybrids of the first generation exceeded the parameters of the father plants' average values and according to the level are close to speltoid mutant, and high extent of phenotype dominance indicates inheritance of these traits according to intermediate, partially dominant and over-dominant types.

Dihybrid segregation in the populations of plants of the second generation into forms with speltoid, squarehead and varieties Lutescens/Erythrospermum ears, with quantitative superiority of speltoid plants indicates control of the feature by two non-allele genes with epistatic interaction. Regardless of genotypes of the varieties of soft wheat, included in the combination of cross-breeding with speltoid mutant, the trait of red colour of the ear determines monogenic dominant pattern of inheritance. Absence of independent inheritance of the traits of the shape of the ear and awnedness in separate phenotype segregation classes indicates linkage of genes which determine the mentioned traits and localization of them in one chromosome.

\section{References}

Ataei, R., Gholamhoseini, M., \& Kamalizadeh, M. (2017). Genetic analysis for quantitative traits in bread wheat exposed to irrigated and drought stress conditions. Phyton, International Journal of Experimental Botany, 86, 228-235.

Beil, G. M., \& Atkins, R. E. (1965). Inheritance of quantitative characters in grain sorghum. Iowa State College Journal of Science, 39(3), 345-348.

Boukid, F., Folloni, S., Sforza, S., Vittadini, E., \& Prandi, B. (2018). Current trends in ancient grains-based foodstuffs: Insights into nutritional aspects and technological applications. Comprehensive Reviewsin Food Science and Food Safety, 17, 123-136.
Breseghello, F. (2013). Traditional and modern plant breeding methods with examples in rice (Oruza sativa L.). Journal of Agricultural and Food Chemistry, 61, 81-124

Burdenyuk-Tarasevich, L. A. (2017). Vykorystannia henetychnoyi nestabilnosti chornobylskykh mutantiv v selektsiyi Triticum aestivum L. na adaptyvnist' [Use of Chornobyl mutants' genetic instability in breeding process of Triticum aestivum L. for adaptability]. Factors in Experimental Evolution of Organisms, 21, 112-116 (in Ukrainian).

Callejo, M. J., Vargas-Kostiuk, M. E., \& Rodríguez-Quijano, M. (2015). Selection, training and validation process of a sensory panel for bread analysis: Influence of cultivar on the quality of breads made from common wheat and spelt wheat. Journal of Cereal Science, 61, 55-62.

Cheng, X., Chai, L., Chen, Z., Xu, L., Zhai, H., Zhao, A., Peng, H., Yao, Y., You, M., Sun, Q., \& Ni, Z. (2015). Identification and characterization of a high kemel weight mutant induced by gamma radiation in wheat (Triticum aestivum L.). BMC Genetics, 16, 127.

Diordiieva, I., Riabovol, L., Serzhuk, O., Novak, A., \& Kotsiuba, S. (2018). The characteristics of wheat collection samples created by Triticum aestivum L./Triticum spelta L. hibridisation. Agronomy Research, 16(5), 2005-2015.

Förster, S., Schumann, E., Weber, W. E., \& Pillen, K. (2012). Discrimination of alleles and copy numbers at the $\mathrm{Q}$ locus in hexaploid wheat using quantitative pyrosequencing. Euphytica, 186, 207-218.

Griffing, B. (1950). Analysis of quantitative gene-action by constant parent regression and related techniques. Genetics, 35, 303-321.

Guo, Z., Zhao, Y., Röder, M. S., Reif, J. C., Ganal, M. W., Chen, D., \& Schnurbusch, T. (2018). Manipulation and prediction of spike morphology traits for the improvement of grain yield in wheat. Scientific Reports, 8, 1-10.

Guzman, C., Xiao, Y., Crossa, J., Gonzalez-Santoyo, H., Huerta, J., Singh, R., \& Dreisigacker S. (2016). Sources of the highly expressed wheat bread making (wbm) gene in CIMMYT spring wheat germplasm and its effect on processing and bread-making quality. Euphytica, 209, 689-692.

Hlebova, L. P., \& Baryisheva, N. V. (2016). Geneticheskiy control' ustoychivosti k steblevoy rzhavchine u introgressivnyh linij tverdoy pshenitsyi, proizvodnyh Triticum timopheevii Zhuk. [Genetic control of stem rust resistance in introgressive durum wheat lines, derivatives Triticum timopheevii Zhuk.]. Biological Bulletin of Bogdan Chmelnitskiy Melitopol State Pedagogical University, 6(3), 121-131 (in Russian).

Huang, D., Zheng, Q., Melchkart, T., Bekkaoui, Y., Konkin, D. J. F., Kagale, S., Martucci, M., You, F. M., Clarke, M., Adamski, N. M., Chinoy, C., Steed, A., McCartney, C. A., Cutler, A. J., Nicholson, P., \& Feurtado, J. A. (2020). Dominant inhibition of awn development by a putative zinc-finger transcriptional repressor expressed at the B1 locus in wheat. New Phytologist, 225, 340-355.

Khoury, C. K., Bjorkman, A. D., Dempewolf, H., Ramirez-Villegas, J., Guarino, L., Jarvis, A., Rieseberg, L. H., \& Struik, P. C. (2014). Increasing homogeneity in global food supplies and the implications for food security. Proceedings of the National Academy of Sciences of the USA, 18, 4001-4006.

Konopatskaia, I., Vavilova, V., Blinov, A., \& Goncharov, N. P. (2016). Spike morphology genes in wheat species (Triticum L.). Proceedings of the Latvian Academy of Sciences, Section B, 70(6), 345-355.

Li, H., Rasheed, A., Hickey, L. T., \& He, Z. (2018). Fast-forwarding genetic gain. Trends Plant Science, 23, 184-186.

Longin, C. F. H., Ziegler, J., Schweiggert, R., Koehler, P., \& Carle, T. (2016). Comparative study of hulled (einkorn, emmer, and spelt) and naked wheats (durum and bread wheat): Agronomic performance and quality traits. Crop Science, 56(1), 302-311

Mondal, S., Rutkoski, J. E., Velu, G., Singh, P. K., Crespo-Herrera, L. A., Guzmán, C., Bhavani, S., Lan, C., He, X., \& Singh, R. P. (2016). Harnessing diversity in wheat to enhance grain yield, climate resilience, disease and insect pest resistance and nutrition through conventional and modern breeding approaches. Frontiers in Plant Science, 7, 991.

Morgun, V. V., \& Yakimchuk, R. A. (2015). Mutahenna aktyvnist' radionuklidnykh zabrudnen' blyzhnoyi zony Chomobylskoyi AES u viddaleni stroky pislia avariyi [Mutagenic activity of radionuclide contamination of the near zone of Chornobyl nuclear power plant (ChNPP) in the long term after the accident]. Plant Physiology and Genetics, 47(6), 463-473 (in Ukrainian).

Morgun, V. V., Sichkar, S. M., Pochinok, V. M., Ninieva, A. K., \& Chugunkova, T. V. (2016). Kharakterystyka kolektsinykh zrazkiv spelty (Triticum spelta L.) za elementamy struktury produktyvnosti ta khlibopekarskoiu yakistyu [Characterization of spelt collection samples (Triticum spelta L.) by elements of plant productivity structure and baking quality]. Plant Physiology and Genetics, 48(2), 112-119 (in Ukrainian).

Mukhordova, M. E. (2019). Vliyanie processa formirovaniya na produktivnost rastenij gibridov ozimoj myagkoj pshenicy v usloviyah Zapadnoj Sibiri [Influence of formation process on plant productivity of winter soft wheat hybrids in the conditions of Western Siberia]. Vestnik of Ulyanovsk State Agricultural Academy, 48(4), 72-77 (in Russian). 
Neyhart, J. L., Lorenz, A. J., \& Smith, K. P. (2019). Multi-trait improvement by predicting genetic correlations in breeding crosses. G3: Genes, Genomes, Genetics, 9(10), 3153-3165.

Rapp, M., Beck, H., Heilig, W., Starck, P., Cuendet, C., Uhlig, F., Kurz, T., \& Longin, C. F. H. (2017). Spelt: Agronomy, quality, favor of its breads from 30 varieties tested across multiple environments. Crop Science, 57(2), 734-747.

Schulthess, A. W., Reif, J. C., Ling, J., Plieske, J., Kollers, S., Ebmeyer, E., Korzun, V., Argillier, O., Stiewe, G., Ganal, M. W., Röder, M. S., \& Jiang, Y. (2017). The roles of pleiotropy and close linkage as revealed by association mapping of yield and correlated traits of wheat (Triticum aestivum L.). Joumal of Experimental Botany, 68(15), 4089-4101.

Sharma, P., Aggarwal, P., \& Kaur, A. (2016). Biofortification: A new approach to eradicate hidden hunger. Food Reviews International, 33(1), 1-21.

Simonov, A. V., Pshenichnikova, T. A., Lapochkina, I. F., \& Watanabe, N. (2015). Vzaimodejstvie genov, opredelyayushih formu kolosa myagkoj pshenicy i raspolozhenie $\mathrm{v}$ hromosome 5AL [Interaction of genes determining the spike shape of wheat and located in 5AL chromosome]. Vavilov Joumal of Genetics and Breeding, 19(6), 57-64 (in Russian).

Simonov, A. V., Pshenichnikova, T. A., Lapochkina, I. F., \& Watanabe, N. (2017) Interaction of genes determining the spike shape of wheat and those located in the 5AL chromosome. Russian Joumal of Genetics: Applied Research, 7, 21-28.

Suchowilska, E., Wiwart, M., Krska, R., \& Kandler, W. (2020). Do Triticum aestivum L. and Triticum spelta L. hybrids constitutr a promising source material for quality breeding of new wheat varieties? Agronomy, 43(10), 2-16.

Tadesse, W., Amri, A., Ogbonnaya, F. C., Sanchez-Garcia, M., Sohail, Q., \& Baum, M. (2016). Wheat: Genetic and genomic resources for grain cereals improvement. Academic Press, Oxford.
Valekzhanin, V. S., \& Korobeinikov, N. I. (2019). Izmenchivost i harakter nasledovaniya massy 1000 zeren u sortov i gibridov myagkoj yarovoj pshenicy v diallelnyh skreshivaniyah [Variability and inheritance of 1000-kernel weight in diallel crosses of Common Spring Wheat]. Achievements of Science and Technology of AICis, 33(3), 42-44 (in Russian).

Voss-Fels, K. P., Stahl, A., \& Hickey, L. T. (2019). Q\&A: Modern crop breeding for future food security. BMC Biology, 17(1), 2-7.

Würschum, T., Jähne, F., Langer, S. M., Longin, C. F. H., Tucker, M. R., \& Leiser, W. L. (2020). Misexpression of a transcriptional repressor candidate provides a molecular mechanism for the suppression of awns by Tipped 1 in wheat. Journal of Experimental Botany, 71(12), 3428-3436.

Xie, Q., Mayes, S., \& Sparkes, D. L. (2015). Spelt as a genetic resource for yield component improvement in bread wheat. Crop Science, 55(6), 2753-2765.

Xu, B. J., Chen, Q., Zheng, T., Jiang, Y. F., Qiao, Y. Y., Guo, Z. R., Cao, Y. L., Wang, Y., Zhang, Y. Z., Zong, L. J., Zhu, J., Liu, C. H., Jiang, Q. T., Lan, X. J., Ma, J., Wang, J. R., Zheng, Y. L., Wei, Y. M., \& Qi, P. F. (2018). An overexpressed $Q$ allele leads to increased spike density and improved processing quality in common wheat (Triticum aestivum). G3: Genes, Genomes, Genetics, 8(3), 771-778.

Yakimchuk, R. A. (2019). Genetic consequences of the contamination of the environment with natural and techno-genic mutagenic factors. Lohos, Kyiv (in Ukrainian)

Yurchenko, T. V., \& Voloshchuk, S. I. (2016). Variabelnist' hospodarskykh oznak u hibrydnykh pokolinnyakh pshenytsi miakoyi ozymoyi za diyi mutaheniv [Variability of agronomic traits in hybrid generations of bread winter wheat induced with mutagens]. Myronivka Bulletin, 2, 156-170 (in Ukrainian). 